\title{
Physical, Atomic and Thermal Properties of Biofield Treated Lithium Powder
}

Mahendra Kumar Trivedi', Rama Mohan Tallapragada', Alice Branton'1, Dahryn Trivedi', Gopal Nayak', Omprakash Latiyal ${ }^{2}$ and Snehasis Jana ${ }^{2 *}$

${ }^{1}$ Trivedi Global Inc., 10624 S Eastern Avenue Suite A-969, Henderson, NV 89052, USA

${ }^{2}$ Trivedi Science Research Laboratory Pvt Ltd, Hall-A, Chinar Mega Mall, Chinar Fortune City, Hoshangabad Rd, Bhopal, Madhya Pradesh, India

\begin{abstract}
Lithium has gained extensive attention in medical science due to mood stabilizing activity. The objective of the present study was to evaluate the impact of biofield treatment on physical, atomic, and thermal properties of lithium powder. The lithium powder was divided into two parts i.e., control and treatment. Control part was remained as untreated and treatment part received Mr. Trivedi's biofield treatment. Subsequently, control and treated lithium powder samples were characterized using X-ray diffraction (XRD), Differential scanning calorimetry (DSC), Thermogravimetric analysis-differential thermal analysis (TGA-DTA), Scanning electron microscopy (SEM) and Fourier transform infrared spectroscopy (FT-IR). XRD data showed that lattice parameter, unit cell volume, density, atomic weight, and nuclear charge per unit volume of lithium were altered after biofield treatment. The crystallite size of treated lithium was increased by $75 \%$ as compared to control. DSC analysis exhibited an increase in melting temperature of treated lithium powder upto $11.2 \%$ as compared to control. TGA-DTA analysis result showed that oxidation temperature, which found after melting point, was reduced upto $285.21^{\circ} \mathrm{C}$ in treated lithium as compared to control $\left(358.96^{\circ} \mathrm{C}\right)$. Besides, SEM images of control and treated lithium samples showed the agglomerated micro particles. Moreover, FT-IR analysis data showed an alteration in absorption band $\left(416 \rightarrow 449 \mathrm{~cm}^{-1}\right)$ in treated lithium sample after biofield treatment as compared to control. Overall, data suggested that biofield treatment has significantly altered the physical, atomic, and thermal properties of lithium powder.
\end{abstract}

Keywords: Biofield treatment; Lithium; X-ray diffraction; Differential scanning calorimetry; Thermogravimetric analysis-differential thermal analysis; Scanning electron microscopy; Fourier transform infrared spectroscopy

\section{Introduction}

Lithium is highly reactive, light metal, which is commonly found in various foods such as grains, vegetables, mustard, kelp, and fish blue corn etc. Several lithium salts are used as mood stabilizing drugs, mainly in the treatment of bipolar disorder [1]. Lithium is primarily responsible to prevent mania and reduces the risk of suicide tendency in humans [2]. Overall, in placebo-controlled trials, lithium has been found useful as an adjunct medication for $45 \%$ of patients [3]. In addition, it is widely spread in central nervous system and interacts with many neurotransmitters and receptors, thus increasing serotonin synthesis [4]. Further, it is also reported that lithium ions $\left(\mathrm{Li}^{+}\right)$can increase the release of serotonin or 5-hydroxy tryptamine by neurons in the brain [5]. Furthermore, the most commonly prescribed lithium salts include lithium carbonate $\left(\mathrm{Li}_{2} \mathrm{CO}_{3}\right)$, lithium orotate $\left(\mathrm{C}_{5} \mathrm{H}_{3} \mathrm{LiN}_{2} \mathrm{O}_{4}\right)$, and lithium citrate $\left(\mathrm{Li}_{3} \mathrm{C}_{6} \mathrm{H}_{5} \mathrm{O}_{7}\right)$ for pharmacological treatment in mentally disordered patients $[6,7]$. Thus, by conceiving the usefulness of lithium in pharmaceutical industry, the present study was attempted to investigate an alternative way, which can modify the physical, atomic and thermal properties of lithium powder.

Harold Saton Burr had performed the detailed studies on the correlation of electric current with physiological process and concluded that every single process in the human body had an electrical significance [8]. Recently, it was discovered that all electrical process happening in body have strong relationship with magnetic field as mentioned by Ampere's law $\left(\oint B . d l=\mu_{o} I\right)$ which states that the moving charge produces magnetic fields in surrounding space $[9,10]$. Thus, the human body emits the electromagnetic waves in form of bio-photons, which surrounds the body and it is commonly known as biofield. Therefore, the biofield consists of electromagnetic field, being generated by moving electrically charged particles (ions, cell, molecule etc.) inside the human body. Further, electrocardiography has been extensively used to measure the biofield of human body [11]. Thus, human has the ability to harness the energy from environment or universe and can transmit into any living or non-living object(s) around the Globe. The objects always receive the energy and responding into useful way that is called biofield energy and the process is known as biofield treatment. Mr. Trivedi's unique biofield treatment (The Trivedi effect ${ }^{\circ}$ ) has been known to transform the structural, physical and thermal properties of metals [12,13] and ceramics [14] in material science. In addition biofield treatment had improved the growth and production of agriculture crops [15-17], significantly altered the phenotypic characteristics of various pathogenic microbes $[18,19]$, and altered the medicinal, growth and anatomical properties of ashwagandha [20].

Based on the excellent outcomes of biofield treatment, authors were interested to investigate the effect of biofield treatment on physical, atomic and thermal characteristics of lithium powder using X-ray diffraction (XRD), Differential Scanning Calorimetry (DSC), Thermogravimetric analysis-differential thermal analysis (TG-DTA), Scanning electron microscopy (SEM), and Fourier transform infrared spectroscopy (FT-IR).

\section{Materials and Methods}

The lithium powder was purchased from Alfa Aesar, USA. The sample was equally divided into two parts, considered as control and

\footnotetext{
*Corresponding author: Snehasis Jana, Trivedi Science Research Laboratory Pvt Ltd, Hall-A, Chinar Mega Mall, Chinar Fortune City, Hoshangabad Rd, Bhopal-462 026, Madhya Pradesh, India, Tel: +91-755-6660006; E-mail: publication@trivedisrl.com

Received August 19, 2015; Accepted September 14, 2015; Published September 21, 2015

Citation: Trivedi MK, Tallapragada RM, Branton A, Trivedi D, Nayak G, et al. (2015) Physical, Atomic and Thermal Properties of Biofield Treated Lithium Powder. J Adv Chem Eng 5: 136. doi:10.4172/2090-4568.1000136

Copyright: (c) 2015 Trivedi MK, et al. This is an open-access article distributed under the terms of the Creative Commons Attribution License, which permits unrestricted use, distribution, and reproduction in any medium, provided the original author and source are credited.
} 
treatment. Control part was remained untreated and treatment group was subjected to Mr. Trivedi's biofield energy treatment.

\section{Biofield energy treatment}

The treatment sample was in sealed pack, handed over to Mr. Trivedi for biofield treatment under laboratory conditions. Mr. Trivedi provided the biofield treatment through his energy transmission process to the treated group without touching the sample. The control and treated samples were characterized using XRD, DSC, TGA-DTA, SEM, and FT-IR.

\section{X-ray diffraction (XRD) study}

$\mathrm{XRD}$ analysis of control and treated lithium powder was carried out on Phillips, Holland PW 1710 X-ray diffractometer system, which had a copper anode with nickel filter. The radiation of wavelength used by the XRD system was $1.54056 \AA$. The Kapton tapes were used to prevent the oxidation of the samples from air. The data obtained from this XRD were in the form of a chart of $2 \theta$ vs. intensity and a detailed table containing peak intensity counts, $d$ value $(\AA)$, peak width $\left(\theta^{\circ}\right)$, relative intensity (\%) etc.

Additionally, PowderX software was used to calculate lattice parameter and unit cell volume of control and treated lithium powder samples. The crystallite size $(\mathrm{G})$ was calculated by using Scherrer formula:

\section{$\mathrm{G}=\mathrm{k} \lambda /(\mathrm{b} \operatorname{Cos} \theta)$,}

Here, $\lambda$ is the wavelength of radiation used, $b$ is full width half maximum (FWHM) and $\mathrm{k}$ is the equipment constant (0.94). Furthermore, the percent change in the lattice parameter was calculated using following equation:

$$
\% \text { change in lattice parameter }=\frac{\left[A_{\text {Treated }}-A_{\text {Control }}\right]}{A_{\text {Control }}} \times 100
$$

Where $\mathrm{A}_{\text {Control }}$ and $\mathrm{A}_{\text {Treated }}$ are the lattice parameter of treated and control samples respectively. Similarly, the percent change in all other parameters such as unit cell volume, density, atomic weight, and crystallite size were calculated.

\section{Differential scanning calorimetry (DSC)}

Differential Scanning Calorimeter (DSC) of Perkin Elmer/ Pyris-1, USA, with a heating rate of $10^{\circ} \mathrm{C} / \mathrm{min}$ and nitrogen flow of $5 \mathrm{~mL} / \mathrm{min}$ was used. The melting point and latent heat of fusion of control and treated lithium were recorded from their respective DSC curves. This system had accuracy of $\pm 0.2 \mathrm{~K}$ in the measurement of melting point.

The percent change in melting point was computed using following equations:

$$
\% \text { change in melting point }=\frac{\left[T_{\text {Treated }}-T_{\text {Control }}\right]}{T_{\text {Control }}} \times 100
$$

Where, $\mathrm{T}_{\text {Control }}$ and $\mathrm{T}_{\text {Treated }}$ are the melting point of control and treated samples, respectively. Similarly, the percent change in the latent heat of fusion was computed.

\section{Thermogravimetric analysis-differential thermal analysis (TG-DTA)}

For TG-DTA analysis, Mettler Toledo simultaneous TG and Differential thermal analyser (DTA) was used. The samples were heated from room temperature to $400^{\circ} \mathrm{C}$ with a heating rate of $5^{\circ} \mathrm{C} /$ min under air atmosphere.

\section{Scanning electron microscopy (SEM)}

Surface morphology is the unique properties of lithium powder. Control and treated lithium samples were observed using JEOL JSM6360 SEM instrument at $2000 \mathrm{X}$ magnification. In order to prevent the sample from oxidising, the environment holder and airlock system were used. With the help of these systems, the sample were prepared and mounted on environmental holder in a sealed glove box and kept in SEM for analysis. The differences in the tendency of the particles to clump were easily seen at the lower magnifications, while variations in size and morphology become clearer at higher magnification [21].

\section{Fourier transform infrared spectroscopy (FT-IR)}

FT-IR spectroscopic analysis was carried out to evaluate the impact of biofield treatment at atomic and molecular level like bond strength, stability, and rigidity of structure etc. FT-IR analysis of control and treated Lithium samples were performed on Shimadzu, Fourier transform infrared (FT-IR) spectrometer with frequency range of 300$4000 \mathrm{~cm}^{-1}$.

\section{Results and Discussion}

\section{X-ray diffraction (XRD) study}

XRD diffractograms of control and treated lithium powders are shown in Figure 1. XRD patterns of control sample showed intense peaks at $2 \theta$ equal to $32.58^{\circ}, 35.56^{\circ}, 35.74^{\circ}, 36.13^{\circ}, 51.48^{\circ}, 51.87^{\circ}, 64.57^{\circ}$ and $76.73^{\circ}$. However, crystalline peaks in treated lithium sample were observed at $2 \theta$ equal to $32.67^{\circ}, 36.15^{\circ}, 52.16^{\circ}, 64.56^{\circ}, 64.84^{\circ}$ and $65.02^{\circ}$. The intense peaks were found in both control and treated samples indicated the crystalline nature of lithium powder. Furthermore, the peaks intensity at $2 \theta$ equal to $36.15^{\circ}$ and $52.16^{\circ}$ in treated samples were significantly reduced as compared to control. Whereas, the intensity of peak at $64.57^{\circ}$ (control), which shifted to $64.84^{\circ}$ (treated), was increased after biofield treatment. The intensity of the diffraction peaks are determined by the arrangement of atoms in the entire crystal and it sums the result of scattering from all atoms in the unit cell to form a diffraction peak $(2 \theta)$ from the particular planes of atoms $[22,23]$. In addition, long range order of atoms along a plane shows higher intensity in XRD as compared to atoms with short range order. Thus, the alteration in intensity of XRD peaks in treated lithium powder as compared to control indicated that arrangement of atoms probably changed after biofield treatment. It is possible that atoms situated along the plane corresponding to $2 \theta$ equal to $36.15^{\circ}$ and $52.16^{\circ}$ may reorient themselves in another direction i.e., along plane attributed to $2 \theta$ equal to $64.57^{\circ}$, after biofield treatment. For further analysis, the XRD peaks were indexed with body centred cubic (BCC) crystal structure [24] and crystal structure parameters such as lattice constant, unit cell volume etc. were computed using PowderX software and results are presented in Table 1 .

Data exhibited that lattice parameter and unit cell volume of treated lithium powder were reduced by 0.15 and $0.46 \%$, respectively as compared to control. The reduction of lattice constant and unit cell volume indicated that a compressive strain might present in unit cell of treated lithium. It is assumed that biofield energy, which probably transferred through biofield treatment, might induce a compressive stress in treated sample. It is reported that high stress on lithium unit cell can change the crystal structure from BCC to face centred cubic (FCC) [25]. Previously, our group reported that biofield treatment had altered the unit cell volume in carbon allotropes [26]. Furthermore, the density and nuclear charge per unit volume of treated lithium powder were increased by 0.45 and $0.46 \%$, respectively; however atomic weight was 

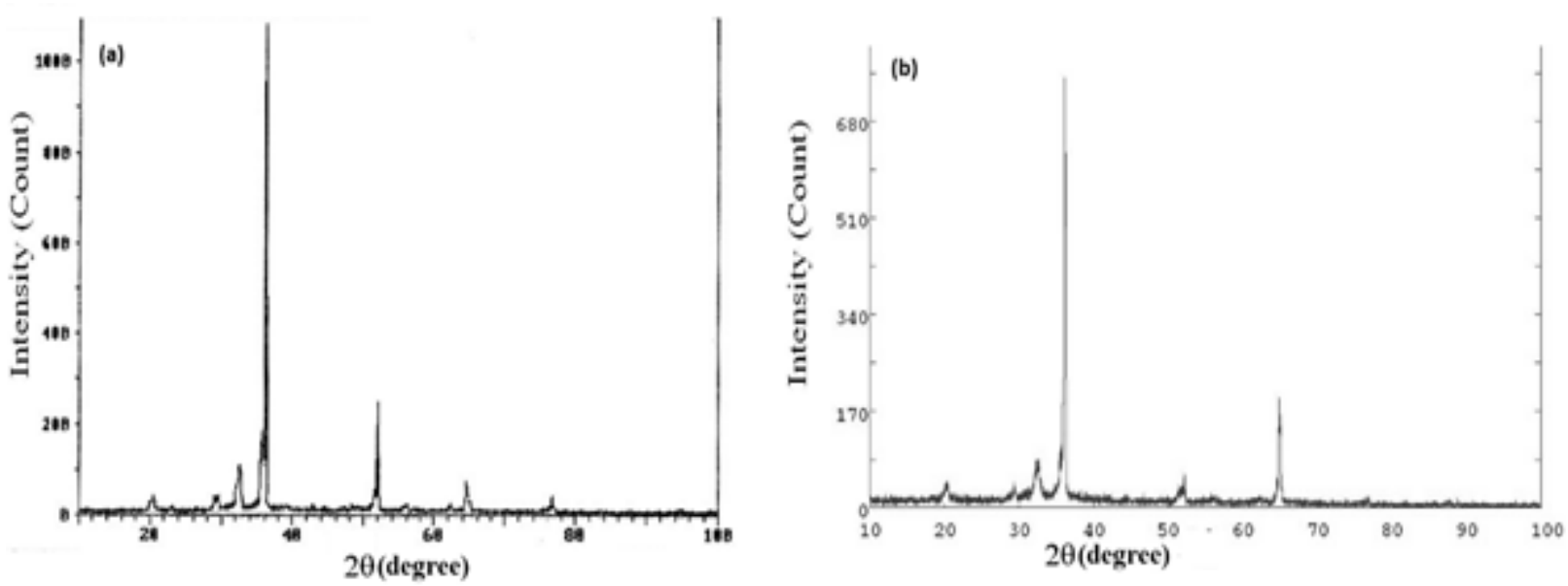

Figure 1: X-ray diffraction (XRD) pattern of lithium powder (a) Control (b) Treated.

\begin{tabular}{|c|c|c|c|c|c|c|}
\hline Group & Lattice parameter $(\AA)$ & $\begin{array}{l}\text { Unit Cell volume } \\
\left(\times 10^{-23} \mathrm{~cm}^{3}\right)\end{array}$ & Density (g/cc) & $\begin{array}{l}\text { Molecular weight } \\
\text { (g/mol) }\end{array}$ & $\begin{array}{l}\text { Nuclear charge per unit volume } \\
\left(\mathrm{C} / \mathrm{m}^{3}\right)\end{array}$ & Crystallite size (nm) \\
\hline Control & 3.52 & 4.36 & 0.537 & 7.06 & 21005 & 62.17 \\
\hline Treated & 3.51 & 4.34 & 0.539 & 7.03 & 21102 & 108.80 \\
\hline Percent Change & -0.14 & -0.46 & 0.46 & -0.45 & 0.46 & 75.0 \\
\hline
\end{tabular}

Table 1: X-ray diffraction (XRD) analysis result of control and treated lithium powder samples.

reduced $(7.060 \rightarrow 7.028)$ by $0.46 \%$ as compared to control. The increase in nuclear charge per unit volume indicated that nuclear strength of $\mathrm{Li}^{+}$ions in treated lithium powder probably increased after biofield treatment. It is reported that $\mathrm{Li}^{+}$plays an important role in central nervous system in releasing the serotonin from neurons $[5,27,28]$. Thus, it is assumed that serotonin releasing activity of $\mathrm{Li}^{+}$in treated sample may be higher as compared to control. Besides, crystallite size $(G)$, computed using Scherrer formula $(G=k \lambda / b \cos \theta)$, are presented in Table 1. The crystallite size was increased from 62.17 $\mathrm{nm}$ (control) to $108.8 \mathrm{~nm}$ in treated lithium powder after biofield treatment. It indicated that crystallite size of lithium powder was significantly increased by $75 \%$ as compared to control, after biofield treatment. It is reported that crystallite size of metals and ceramics can be increased by increasing the temperature [29,30]. Recently, the increase in crystallite size in nickel and copper through biofield treatment had been reported by our group [31]. Thus, it is assumed that the energy transferred through biofield treatment probably initiated the movement of crystallite boundaries, which might lead to increase the crystallite size. Hence, XRD data revealed that biofield treatment has altered the physical and structural properties of lithium powder.

\section{Differential scanning calorimetry (DSC)}

Melting point and latent heat of fusion are the two key parameters for thermal analysis of metal powder. Fundamentally, melting point is related to the kinetic energy (thermal vibration) of atoms, whereas the potential energy is the energy required to overcome the interatomic interaction for phase change, which is related to latent heat of fusion $(\Delta \mathrm{H})[32]$. The melting temperature and latent heat of fusion of control and treated lithium powder are presented in Table 2 . The melting temperature of control lithium sample was found at $181.86^{\circ} \mathrm{C}$ which changed to $181.20^{\circ} \mathrm{C}, 202.21^{\circ} \mathrm{C}$, and $200.34^{\circ} \mathrm{C}$ in treated samples i.e., $\mathrm{T} 1, \mathrm{~T} 2$, and $\mathrm{T} 3$, respectively. It showed that melting temperature of treated lithium powder was increased by 11.2 and $10.2 \%$ in $\mathrm{T} 2$ and $\mathrm{T} 3$, respectively, though it was slightly decreased $(0.36 \%)$ in $\mathrm{T} 1$, as compared to control. Thus, the alteration of melting point was found in treated lithium powder indicated that the thermal vibrations of atoms probably changed after biofield treatment. The latent heat of fusion in control sample was $309.15 \mathrm{~J} / \mathrm{g}$, which changed to $42.41,234.48$, and $404.38 \mathrm{~J} / \mathrm{g}$ in treated lithium T1, T2, and T3, respectively as compared to control. Recently, our group reported that biofield treatment had altered the melting point and $\Delta \mathrm{H}$ in lead and tin powder [33]. In addition, the change in $\Delta \mathrm{H}$ suggests that potential energy of treated lithium atoms possibly changed after biofield treatment. Thus, it is assumed that the biofield treatment probably transferred the energy to lithium powder and that might be responsible for alteration in kinetic and potential energy of treated atoms. Additionally, the increase in melting temperature in treated sample also suggests that interatomic interaction of treated lithium probably enhanced after biofield treatment. Furthermore, it is reported that $\mathrm{Li}^{+}$interact with nitric oxide (NO) in CNS of human, which plays a crucial role in the neural plasticity [34,35]. The interaction of two atoms directly depends on their mobility and interatomic interaction of respective atoms [36]. Hence it is assumed that the alteration in interatomic interaction of treated lithium atoms may change the interaction of $\mathrm{Li}^{+}$with $\mathrm{NO}$ and that can ultimately influence the mood stabilizing activity of lithium.

\section{Thermogravimetric analysis-differential thermal analysis (TG-DTA)}

Analysis result of TG-DTA is presented in Table 3. Data showed the exothermic peak at $358.96^{\circ} \mathrm{C}$ (control), which reduced to $305.42^{\circ} \mathrm{C}$, $349.56^{\circ} \mathrm{C}, 285.21^{\circ} \mathrm{C}$ and $328.06^{\circ} \mathrm{C}$ in treated lithium samples i.e., $\mathrm{T} 1$, $\mathrm{T} 2, \mathrm{~T} 3$, and T4, respectively. It could be due to oxidation of control and treated lithium powder samples. It indicated that oxidation temperature was reduced by $14.9,2.61,20.5$, and $8.60 \%$ in treated lithium powder $\mathrm{T} 1, \mathrm{~T} 2, \mathrm{~T} 3$, and T4, respectively as compared to control. The reduction of oxidation temperature of treated samples as compared to control indicated that thermal stability of lithium powder probably decreased after biofield treatment. Therefore, based on DSC and TG-DTA data, it 


\begin{tabular}{|l|l|l|l|l|}
\hline Parameter & Control & T1 & T2 & T3 \\
\hline Melting Temperature $\left({ }^{\circ} \mathrm{C}\right)$ & 181.86 & 181.20 & 202.21 & 200.34 \\
\hline Percent change & - & -0.36 & 11.2 & 10.2 \\
\hline Latent heat of fusion, $\Delta \mathrm{H}(\mathrm{J} / \mathrm{g})$ & 309.15 & 42.41 & 234.48 & 404.38 \\
\hline Percent change in $\Delta \mathrm{H}$ & - & -86.3 & -24.1 & 30.8 \\
\hline
\end{tabular}

Table 2: Differential scanning calorimetry (DSC) analysis of control and treated of lithium powder samples.

\begin{tabular}{|l|l|l|l|l|l|}
\hline Parameter & Control & T1 & T2 & T3 & T4 \\
\hline Oxidation Temperature $\left({ }^{\circ} \mathrm{C}\right)$ & 358.96 & 305.42 & 349.56 & 285.21 & 328.06 \\
\hline Percent increase/ decrease & & -14.9 & -2.61 & -20.5 & -8.60 \\
\hline
\end{tabular}

Table 3: Thermogravimetric analysis-differential thermal analysis (TG-DTA) of control and treated lithium powder samples.

is concluded that biofield treatment has altered the thermal behaviour of lithium powder.

\section{Scanning electron microscopy (SEM)}

SEM images of control and treated lithium powders are shown in Figure 2. It showed that powder particles were irregular and highly agglomerated in control and treated lithium powders. The SEM micrograph of control showed inter-particles and interagglomerated boundaries whereas treated sample showed the possible fracture and welding at the surface on the particles. Recently, our group had studied the effect of biofield treatment on antimony and bismuth powders using SEM, in which fractured surfaces were observed after treatment [37]. Thus, it is assumed that biofield treatment may induce the fracture in treated powder particles, which led to generate fresh surfaces. Further, these fresh surfaces welded together to form agglomerated powders. Therefore, SEM images revealed that biofield treatment has altered the surface morphology of lithium powder.

\section{Fourier transform infrared spectroscopy (FT-IR)}

The FT-IR spectrum serves as compound's fingerprint and provides specific information about chemical bonding and molecular structure. Thus FT-IR is more advanced and powerful analytical tool for characterization and identification of molecules. The FTIR spectra of control and treated lithium powders are presented in Figure 3. In these spectra, the absorption band was observed at 3566 and $3674 \mathrm{~cm}^{-1}$ in control and treated lithium samples respectively, which were attributed to $\mathrm{O}-\mathrm{H}$ stretching vibrations. Brooker et al. reported that the lithium compounds are highly air-sensitive so it can absorb the air and water easily [38]. Thus, it is possible that the lithium metal powder used in this experiment may absorb moistures from the environment. Due to which, the $\mathrm{O}-\mathrm{H}$ bands were emerged in FT-IR spectra of control and treated samples. Furthermore, the absorption band found at 862,1001 , and $1446 \mathrm{~cm}^{-1}$ in control and 867,1085 , and $1446 \mathrm{~cm}^{-1}$ in treated sample were corresponding to bending, symmetric stretching, and asymmetric stretching vibrations of $-\mathrm{CO}_{3}$ group. The emergence of $-\mathrm{CO}_{3}$ band could be due to $\mathrm{CO}_{2}$ absorption by samples. In addition, the absorption band corresponding to $\mathrm{Li}-\mathrm{O}$ bond vibrations was observed at $416 \mathrm{~cm}^{-1}$ in control and it was shifted to $449 \mathrm{~cm}^{-1}$ in treated lithium sample. Simonov et al. reported the Li-O bond vibration at around $428 \mathrm{~cm}^{-1}$ in lithium containing compound [39]. Recently, our group reported that the alteration of absorption band in FT-IR spectra of zinc oxide, iron oxide, and copper oxide powders after biofield treatment [40]. Thus, based on this, it is assumed that biofield energy treatment might alter the bonding properties in lithium powder.

\section{Conclusion}

XRD data showed that biofield treatment results in reduction of unit cell volume and atomic weight by $0.46 \%$ as compared to control; however density and nuclear charge per unit volume were increased by 0.45 and $0.46 \%$, respectively as compared to control. Based on the increase in nuclear charge per unit volume in treated lithium sample, it is assumed that nuclear strength of $\mathrm{Li}^{+}$ions might enhanced after biofield treatment. It may lead to increase the efficacy of $\mathrm{Li}^{+}$ions in human brain as mood stabilizer. Besides, the crystallite size was increased from $62.17 \mathrm{~nm}$ (control) to $108.8 \mathrm{~nm}$ in treated lithium powder. The melting point of treated lithium was increased upto $202.21^{\circ} \mathrm{C}$ as compared to control $\left(181.86^{\circ} \mathrm{C}\right)$. Further, the change in melting point can be correlated with the change in interatomic interaction of treated lithium atoms after biofield treatment. It is assumed that the change in interatomic interaction may lead to alter the interaction of $\mathrm{Li}^{+}$ions with $\mathrm{NO}$ in CNS of human. In addition, TG-DTA study revealed that oxidation temperature of lithium was reduced upto $285.21^{\circ} \mathrm{C}$ as compared to control $\left(358.96^{\circ} \mathrm{C}\right)$. SEM image of treated lithium sample showed the fractured and welded surface as compared to inter-particle and agglomerated boundaries in control. FT-IR result showed that, $\mathrm{Li}-\mathrm{O}$ bond in treated sample $\left(449 \mathrm{~cm}^{-1}\right)$ was altered as compared to control $\left(416 \mathrm{~cm}^{-1}\right)$. Overall, data suggested that biofield treatment has altered the physical, atomic, and thermal properties of lithium powder. Therefore, it is assumed that biofield treated lithium powder could be more useful in mood stabilizer drug as compared to control.
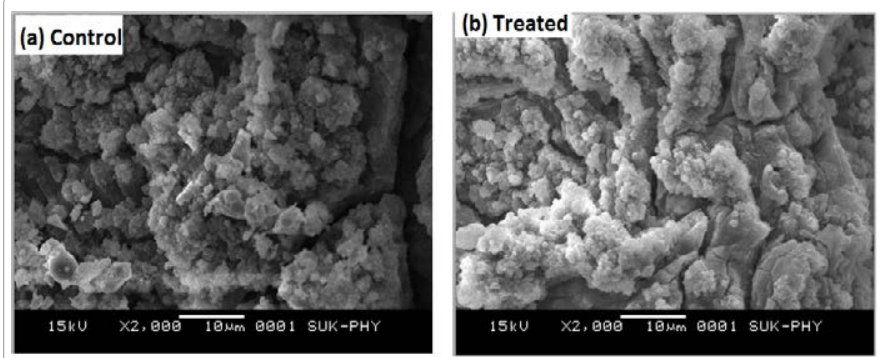

Figure 2: Scanning electron microscope (SEM) images of lithium powder

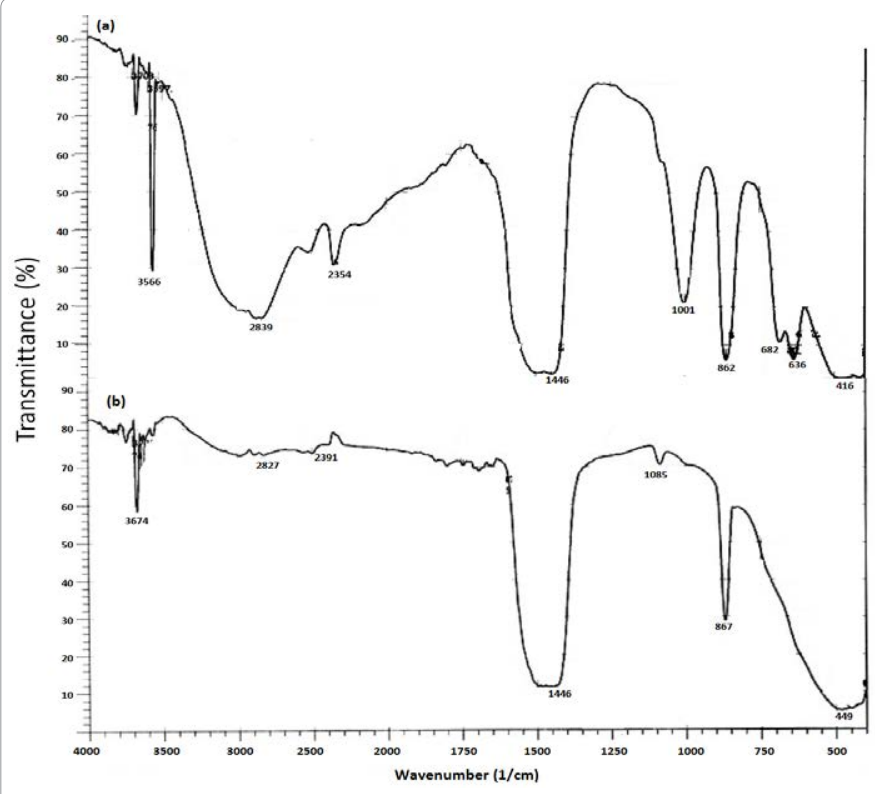

Figure 3: FT-IR spectrum of lithium powder (a) Control and (b) Treated. 
Citation: Trivedi MK, Tallapragada RM, Branton A, Trivedi D, Nayak G, et al. (2015) Physical, Atomic and Thermal Properties of Biofield Treated Lithium Powder. J Adv Chem Eng 5: 136. doi:10.4172/2090-4568.1000136

Page 5 of 5

\section{Acknowledgements}

Authors gratefully acknowledged to Dr. Cheng Dong of NLSC, Institute of Physics, and Chinese academy of Sciences for providing the facilities to use PowderX software for analyzing XRD data. Authors also would like to thank Trived Science, Trivedi master wellness and Trivedi testimonials for their support during the work.

\section{References}

1. Gelenberg AJ, Kane JM, Keller MB, Lavori P, Rosenbaum JF, et al. (1989) Comparison of standard and low serum levels of lithium for maintenance treatment of bipolar disorder. N Engl J Med 321: 1489-1493.

2. Baldessarini RJ, Tondo L, Davis P, Pompili M, Goodwin FK, et al. (2006) Decreased risk of suicides and attempts during long-term lithium treatment: a meta-analytic review. Bipolar Disord 8: 625-639.

3. Bauer M, Forsthoff A, Baethge C, Adli M, Berghöfer A, et al. (2003) Lithium augmentation therapy in refractory depression-update 2002. Eur Arch Psychiatry Clin Neurosci 253: 132-139.

4. Brunton L, Chabner B, Knollman B (2011) Goodman and Gilman's the pharmacological basis of therapeutics. 12th edn, McGraw-Hill Professional, New York, USA

5. Massot O, Rousselle JC, Fillion MP, Januel D, Plantefol M, et al. (1999) 5-HT1B receptors: a novel target for lithium. Possible involvement in mood disorders. Neuropsychopharmacology 21: 530-541.

6. Nieper HA (1973) The clinical applications of lithium orotate. A two years study. Agressologie 14: 407-411.

7. Ebenezer IS (2015) Affective disorders 2: Bipolar disorder. In: Neuropsychopharmacology and Therapeutics. John Wiley \& Sons Ltd, Chichester, UK.

8. Burr HS (1957) Bibliography of Harold Saxton Burr. Yale J Biol Med 30: 163167.

9. Hammerschlag R, Jain S, Baldwin AL, Gronowicz G, Lutgendorf SK, et al. (2012) Biofield research: a roundtable discussion of scientific and methodological issues. J Altern Complement Med 18: 1081-1086.

10. Movaffaghi Z, Farsi M (2009) Biofield therapies: biophysical basis and biological regulations? Complement Ther Clin Pract 15: 35-37.

11. Rivera-Ruiz M, Cajavilca C, Varon J (2008) Einthoven's string galvanometer: the first electrocardiograph. Tex Heart Inst J 35: 174-178.

12. Trivedi MK, Patil S, Tallapragada RM (2012) Thought intervention through bio field changing metal powder characteristics experiments on powder characteristics at a PM plant. Future Control and Automation LNEE 173: 247252

13. Trivedi MK, Patil S, Tallapragada RM (2015) Effect of biofield treatment on the physical and thermal characteristics of aluminium powders. Ind Eng Manage 4: 151.

14. Trivedi MK, Patil S, Tallapragada RM (2013) Effect of biofield treatment on the physical and thermal characteristics of vanadium pentoxide powder. J Material Sci Eng S11: 001.

15. Shinde V, Sances F, Patil S, Spence A (2012) Impact of biofield treatment on growth and yield of lettuce and tomato. Aust J Basic \& Appl Sci 6: 100-105.

16. Lenssen AW (2013) Biofield and fungicide seed treatment influences on soybean productivity, seed quality and weed community. Agricultural Journal 8: $138-143$.

17. Sances F, Flora E, Patil S, Spence A, Shinde V (2013) Impact of biofield treatment on ginseng and organic blueberry yield. Agrivita J Agric Sci 35.

18. Trivedi MK, Patil S, Shettigar H, Gangwar M, Jana S (2015) Antimicrobial sensitivity pattern of Pseudomonas fluorescens after biofield treatment. J Infect Dis Ther 3: 222.

19. Trivedi MK, Patil S, Shettigar H, Bairwa K, Jana S (2015) Phenotypic and biotypic characterization of Klebsiella oxytoca: An impact of biofield treatment. J Microb Biochem Technol 7: 202-205.

20. Nayak G, Altekar N (2015) Effect of biofield treatment on plant growth and adaptation. J Environ Health Sci 1: 1-9.

21. Dercz G, Prusik K, Prusik L (2008) X-ray and SEM studies on zirconia powders. JMME 31: 408-414.
22. Chauhan $A$, Chauhan $P$ (2014) Powder XRD technique and its applications in science and technology. J Anal Bioanal Tech 5: 212.

23. Speakman SA: Basics of X-Ray Powder Diffraction.

24. Olinger B, Shaner JW (1983) Lithium, compression and high-pressure structure. Science 219: 1071-1072.

25. Hanfland M, Syassen K, Christensen NE, Novikov DL (2000) New highpressure phases of lithium. Nature 408: 174-178.

26. Trivedi MK, Tallapragada RM (2009) Effect of super consciousness externa energy on atomic, crystalline and powder characteristics of carbon allotrope powders. Mater Res Innov 13: 473-480.

27. Yeste M, Alvira D, Verdaguer E, Tajes M, Folch J, et al. (2007) Evaluation of acute antiapoptotic effects of $\mathrm{Li}+$ in neuronal cell cultures. J Neural Transm 114: 405-416.

28. Grafe P, Reddy MM, Emmert H, ten Bruggencate G (1983) Effects of lithium on electrical activity and potassium ion distribution in the vertebrate central nervous system. Brain Res 279: 65-76.

29. Rashad MM, El-Shaarawy MG, Shash NM, Maklad MH, Afifi AF (2015) Controlling the composition, microstructure, electrical and magnetic properties of LiFe5O8 powders synthesized by sol gel auto-combustion method using urea as a fuel. J Magn Magn Mat 374: 495-501.

30. Gaber A, Abdel-Rahim MA, Abdel-Latief AY, Abdel-Salam MN (2014) Influence of calcination temperature on the structure and porosity of nanocrystalline $\mathrm{SnO} 2$ synthesized by a conventional precipitation method. Int J Electrochem Sci 9: 81-95.

31. Trivedi MK, Tallapragada RM (2008) A transcendental to changing metal powder characteristics. Met Powder Rep 63: 22-28, 31.

32. Moore JW (2010) Chemistry: The molecular science. 4th edn, Brooks Cole.

33. Trivedi MK, Patil S, Tallapragada RM (2013) Effect of biofield treatment on the physical and thermal characteristics of silicon, tin and lead powders. J Material Sci Eng 2: 125.

34. Ghasemi M, Sadeghipour H, Mosleh A, Sadeghipour HR, Mani AR, et al. (2008) Nitric oxide involvement in the antidepressant-like effects of acute lithium administration in the mouse forced swimming test. Eur Neuropsychopharmacol 18: 323-332.

35. Ghasemi M, Sadeghipour H, Poorheidari G, Dehpour AR (2009) A role for nitrergic system in the antidepressant-like effects of chronic lithium treatment in the mouse forced swimming test. Behav Brain Res 200: 76-82.

36. Grunwald E, Chang KC, Leffler JE (1976) Effects of molecular mobility on reaction rates in liquid solutions. Annu Rev Phys Chem 27: 369-385.

37. Dhabade VV, Tallapragada RM, Trivedi MK (2009) Effect of external energy on atomic, crystalline and powder characteristics of antimony and bismuth powders. Bull Mater Sci 32: 471-479.

38. Brooker MH, Bates JB (1971) Raman and infrared spectral studies of anhydrous Li2CO3 and Na2CO3. J Chem Phys 54: 4788-4796.

39. Simonov AP, Shigorin DN, Tsareva GV, Talalaeva TV, Kocheshkov KA (1965) The infrared absorption spectra and structure of some simpler alkoxldes of lithium, sodium and potassium. J Appl Spectros 3: 398-403.

40. Trivedi MK, Nayak G, Patil S, Tallapragada RM, Latiyal O (2015) Studies of the atomic and crystalline characteristics of ceramic oxide nano powders after bio field treatment. Ind Eng Manage 4: 161. 